\title{
A new species of Roeboides (Teleostei: Characidae) from Costa Rica and Panama, with a key to the middle American species of the genus
}

\author{
Wilfredo A. Matamoros ${ }^{1}$, Prosanta Chakrabarty ${ }^{2}$, Arturo Angulo ${ }^{3}$, \\ Carlos A. Garita-Alvarado ${ }^{3}$, and Caleb D. McMahan ${ }^{2}$
}

A new species of Roeboides is described from the Pacific slope of Costa Rica and Panama. Roeboides bussingi differs from all other Central American Roeboides and all members of the $R$. guatemalensis species group by the following combination of characters: presence of 18-22 scales above the lateral line (vs. 12-16 in R. dientito); 15-22 scales below the lateral line (vs. 10-14 in R. dientito, and 20-24 in R. loftini); an inconspicuous, sometimes absent, crescent-shaped humeral spot (vs. a large round, conspicuous humeral spot in $R$. carti, R. dayi, R. dientonito, $R$. ilseae, $R$. loftini, and $R$. occidentalis); a small wedge-shaped spot that does not reach the lateral line ( $v s$. a large spot crossing the lateral line in R. guatemalensis); a teardrop shaped caudal spot (vs. caudal spot triangle shaped in R. bouchellei); and a dark band at the distal tip of the anal fin (vs. dark band absent in R. bouchellei). A key to all Middle American species of Roeboides is also presented.

Uma espécie nova de Roeboides é descrita da vertente pacífica da Costa Rica e Panamá. Roeboides bussingi difere de todas as outras espécies de Roeboides da América Central e de todos os membros do grupo R. guatemalensis pela seguinte combinação de caracteres: presença de 18-22 escamas acima da linha lateral (vs. 12-16 em R. dientito); 15-22 escamas abaixo da linha lateral (vs. 10-14 em $R$. dientito e 20-24 em $R$. loftini); mancha umeral inconspícua, as vezes ausente, no formato de meia lua ( $v s$. mancha humeral conspicua e arredondada em $R$. carti, $R$. dayi, $R$. dientonito, $R$. ilseae, $R$. loftini e $R$. occidentalis); pequena mancha em forma de cunha, não alcançando a linha lateral ( $v s$. mancha grande, atravessando a linha lateral em $R$. guatemalensis); mancha do pedúnculo caudal em formato de gota d'água ( $v s$. mancha caudal com formato triangular em $R$. bouchellei); banda escura na margem distal da nadadeira anal (vs. banda escura ausente em $R$. Bouchellei). Uma chave para todas as espécies de Roeboides da América Média é fornecida.

Key words: Central America, Characinae, Distribution, Freshwater, Pacific Slope.

\section{Introduction}

Roeboides Günther, 1864 includes 21 valid species (Eschmeyer, 2012). The genus has a wide distribution ranging from río Perros at Ixtepec in southern Mexico (Miller et al., 2005) to the la Plata basin in northern Argentina (Lucena, 2007). Members of Roeboides are best known for their habit of tearing off and ingesting scales from other fishes (lepidophagy), which is presumably aided by conspicuous teeth on the external margin of the jaws
(Hahn et al., 2000). The genus has its greatest species richness in South America (15 species), whereas in Central America only seven valid species are known, including the recently described Roeboides loftini Lucena, 2011. Six of these species are restricted to Lower Middle America (Costa Rica and Panama). Roeboides bouchellei is the only Middle American species with a large distributional range, extending from Panama to Southern Mexico (Miller et al., 2005). Notably one third of all species of Roeboides have been described in the last decade.

${ }^{1}$ Department of Biological Sciences, the University of Southern Mississippi, 118 College Dr. Box 5018, Hattiesburg, MS 39401, USA. wilmatamoros@yahoo.com

${ }^{2}$ Museum of Natural Science, Ichthyology Section, Department of Biological Sciences, Louisiana State University. 119 Foster Hall, Baton Rouge, LA 70803, USA. prosanta@1su.edu (PC), cmcmah2@1su.edu (CDM)

${ }^{3}$ Museo de Zoología, Escuela de Biología, Universidad de Costa Rica, San Pedro, San José, Costa Rica 11501-2060. cagaritab@gmail.com (CGA), arturo.angs@gmail.com (AA) 
Lucena (1998) proposed that the species of Roeboides could be organized into four groups: the $R$. dispar group, the $R$. guatemalensis group, the $R$. microlepis group, and the $R$. affinis group. Those groups of species are defined by unique osteological synapomorphies (particularly of the jaws) as well as meristic traits (Lucena, 2000, 2003, 2007, 2011). All species of Roeboides from Central America (viz., R. bouchellei, $R$. carti, $R$. dayi, $R$. guatemalensis, $R$. ilseae, $R$. loftini, and $R$. occidentalis) belong to the $R$. guatemalensis group. Roeboides dientonito, from Guyana and Venezuela, is the only member of the $R$. guatemalensis group not found in Central America (Lucena, 2007).

According to Bussing (1998), a preliminary molecular analysis provided evidence that an unidentified species of Roeboides from Costa Rica and Panama was distinct from other valid species of the genus. Bussing (1998) also noted that morphological evidence in favor of that distinction was lacking at the time. In January and April 2011, additional specimens of that species were collected from several localities in Costa Rica and Panama (Fig. 1). That new species of Roeboides is described herein, and a key to Middle American species of the genus is provided.

\section{Material and Methods}

Specimens examined are deposited in the Louisiana State University Museum of Natural Science (LSUMZ), Museo de Zoología, Universidad de Costa Rica (UCR), Florida

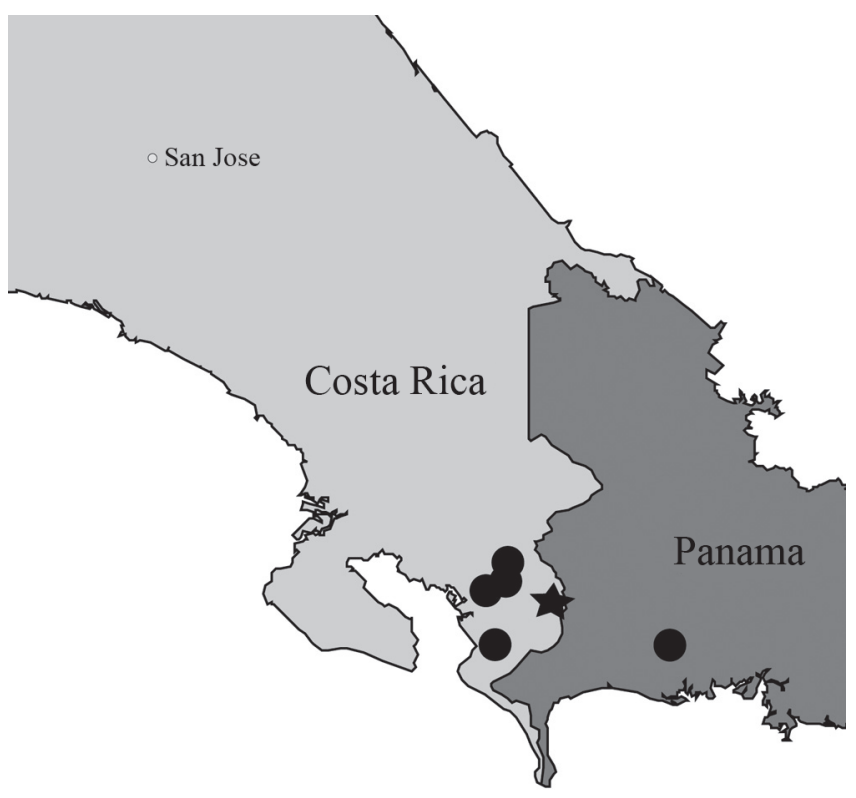

Fig. 1. Distribution of Roeboides bussingi. Holotype indicated by the star, circles represent paratypes.
Museum of Natural History (UF), and Tulane University (TU). Morphometric measurements were taken for 17 distances in 29 specimens of the species described herein. Comparative information on other valid species of Roeboides was obtained from Bussing (1985), Lucena (2000) and Lucena (2011) and from specimens listed in the Comparative Material. Measurements were taken following Fink \& Weitzman (1974). Measurements were recorded to the nearest $0.1 \mathrm{~mm}$ using dial calipers, and include: standard length (SL), head length (HL), orbit diameter, snout length, maxillary length, bony interorbital length, greatest body depth, caudal peduncle depth, caudal peduncle length, predorsal distance, pre-anal distance, pre-pectoral distance, prepelvic distance, height of the dorsal fin, height of the anal fin, pectoral-fin length, and pelvic-fin length. Morphometric measurements are presented as percentages of SL. Meristic counts include: anal-fin rays, pectoral-fin rays, pelvic-fin rays, caudal-fin rays, lateral line scales, scales above lateral line, scales below lateral line, and scales around caudal peduncle.

\section{Results}

\section{Roeboides bussingi, new species Figs. 2a-b}

Roeboides sp.; Bussing (1998)

Holotype. LSUMZ 14799, 74.9 mm SL, Costa Rica, Puntarenas Province, río Coloradito, about $6 \mathrm{~km}$ from the main road, tributary of the río Coto drainage, $08^{\circ} 34$ '12"N 82॰51'33”W, W. A. Matamoros, C. D. McMahan, C. Garita, A. Angulo \& P. Chakrabarty, 18 Feb 2011.

Paratypes. Costa Rica: LSUMZ 14629, 6, 54.4-63.7 mm SL, same data as holotype; LSUMZ 14601, 4, 53.3-39.4 mm SL, Puntarenas Province, Puente Las Monjas at bridge in community

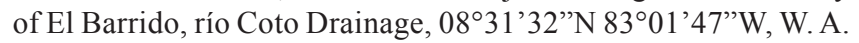
Matamoros, C. D. McMahan, C. Garita, A. Angulo \& P. Chakrabarty, 17 Feb 2011; LSUMZ 14623, 1, 50.9 mm SL, Puntarenas Province, near city of río Claro, about $4 \mathrm{~km}$ from town of río Claro, río Claro drainage, $08^{\circ} 37^{\prime} 28^{\prime \prime} \mathrm{N} 83^{\circ} 03$ '59'W, W. A. Matamoros, C. D. McMahan, C. Garita, A. Angulo \& P. Chakrabarty, 17 Feb 2011; LSUMZ 14655, 2, 54.5-60.6 mm SL, Puntarenas Province, río Caracol, small bridge on main road, tributary of the río Claro, $08^{\circ} 40^{\prime} 48^{\prime} \mathrm{N} 83^{\circ} 00^{\prime} 25^{\prime}$ W, W. A. Matamoros, C. D. McMahan, C. Garita, A. Angulo \& P. Chakrabarty, 19 Feb 2011. UCR 0756, 20, 49.2-92.8 mm SL, Puntarenas Province, río Caracol on the Inter-American highway, río Coto Draiange, $7 \mathrm{~km}$ E of Pueblo río Claro, 08³9'55.96”N 8301'34.4'W, W. A. Bussing, M. I. Bussing \& E. Bussing, 27 Feb 1973. Panama: LSUMZ 14797, 1, 79.0 mm SL, Chiriquí Province, río San Pablo, near town of San Pablo, west of city of David, $08^{\circ} 25^{\prime} 44^{\prime \prime N} 82^{\circ} 29^{\prime} 45^{\prime}$ W, W. A. Matamoros, C. D McMahan \& M. P. Davis, 10 Apr 2011; UCR 0450, 5, 46.2-68.5 $\mathrm{mm}$ SL, river of unknown name $30 \mathrm{~km}$ east of Paso Canoas, $1 \mathrm{~km}$ west of río Concepcion bridge at Inter-American Highway, W. A. Bussing \& M. I. Bussing, 25 Jan 1971. 

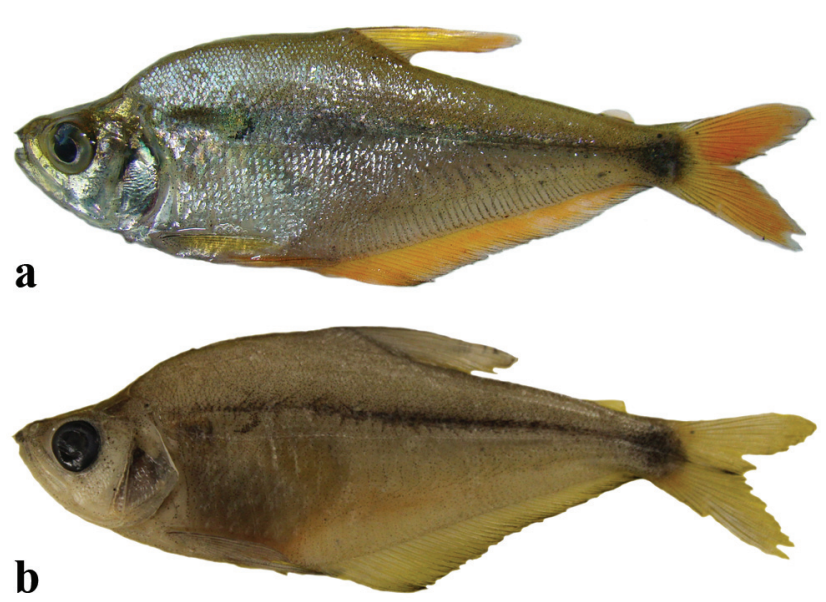

Fig. 2. Photographs of (a) Roeboides bussingi (LSUMZ 14629; $69.2 \mathrm{~mm} \mathrm{SL}$ ) depicting live coloration, and (b) preserved holotype (LSUMZ 14799; $74.9 \mathrm{~mm} \mathrm{SL}$ ).

Diagnosis. Roeboides bussingi differs from all other members of the $R$. guatemalensis group by the following combination of characters: the presence of 18-22 scales above lateral line (vs. 12-16 in R. dientito), 15-22 scales below lateral line (vs. 1014 in R. dientito, and 20-24 in R. loftini), a small inconspicuous, sometimes absent, crescent-shaped humeral spot ( $v s$. a large round, conspicuous humeral spot in $R$. carti, $R$. dayi, $R$. dientonito, $R$. ilseae, $R$. loftini, and $R$. occidentalis), and the presence of a small wedge-shaped spot that does not reach the lateral line (vs. a large spot crossing the lateral line in $R$. guatemalensis). Roeboides bussingi and $R$. bouchellei share a similar humeral spot, and both lack a wedge-shaped spot on the lateral line between the dorsal and anal fins. However, $R$. bussingi can be distinguished from $R$. bouchellei by an overall darker body coloration with many scattered melanophores ( $v S$. a lighter colored body with few melanophores; most evident in preserved specimens and consistent across genders), by a dark band of melanophores at the distal tip of the anal fin (vs. distal band absent; melanophores scattered throughout anal fin; Fig. $3 \mathrm{a}$ and $\mathrm{b}$ ), a darker, more developed teardrop shaped caudal spot with the rounded bulbous posterior end on the caudal fin (vs. a lighter, less developed triangular spot typically restricted to the caudal peduncle; Fig. $3 \mathrm{c}$ and d), and a lighter lateral band ( vs. a darker, more developed lateral band; most evident in preserved specimens).

Description. Morphometric and meristic data for type specimens are summarized in Table 1. Roeboides bussingi is a laterally compressed characin with a strongly concave nape and a convex, hump-shaped nuchal region. Greatest body depth between dorsal- and anal-fin origins. Post-dorsal profile straight, angling ventrally from the dorsal-fin origin to caudalfin origin. Pre-anal profile rounded from tip of snout to analfin origin, post-anal profile straight along the anal fin, angling ventrally at the caudal peduncle.

Mouth terminal with strongly inclined gape. Upper jaw protrudes over lower jaw. Maxilla reaches slightly past vertical through midline of pupil. Premaxilla and dentary with unicuspid mammiliform teeth exposed on outer margin of lips. Largest mammiliform teeth larger than internal buccal teeth. Two large mammiliform teeth projecting from anterior margin of upper lip. Two small mammiliform teeth on the dentary directly below those on the margin of the upper lip. Buccal teeth unicuspid and conical, in single irregular row on both jaws (tooth morphology identical to other species of the R. guatemalensis group). Dorsal-fin origin slightly posterior to vertical through anal-fin origin. Pelvic-fin rays extending beyond anal-fin origin. Pectoral-fin rays not reaching origin of anal fin. Small bony hooks present in the segmented rays of the anal fin, as described by Lucena (2011) for R. loftini.

Color in life. Overall coloration silvery (transparent where scales are absent), with a greenish-silvery lateral band. All fins yellow to orange. Distal tips of anal and caudal fins with dusky distal margins. Conspicuous dark teardrop-

Table 1. Morphometric and meristic data of holotype $(\mathrm{H})$ and paratypes $(\mathrm{n}=28)$ of Roeboides bussingi. Holotype is not included in the range, mean and standard deviation (SD).

\begin{tabular}{|c|c|c|c|c|}
\hline Morphometrics & $\mathrm{H}$ & Mean & Range & SD \\
\hline Standard length & 74.9 & 59.2 & $44.2-79.5$ & 9.5 \\
\hline Head length & 26.9 & 15.9 .9 & $11.7-21.3$ & 2.1 \\
\hline \multicolumn{5}{|c|}{ Percentages of standard length } \\
\hline Greatest body depth & 35.3 & 34.9 & $32.3-37.5$ & 1.6 \\
\hline Caudal peduncle depth & 9.4 & 8.7 & $7.7-9.4$ & 0.5 \\
\hline Caudal peduncle length & 7.2 & 8.3 & $6.5-9.9$ & 1.1 \\
\hline Predorsal length & 51.3 & 48.1 & $44.0-51.3$ & 1.7 \\
\hline Preanal length & 45.4 & 45.6 & $42.0-48.8$ & 2.2 \\
\hline Prepectoral length & 23.4 & 26.5 & $23.3-45.1$ & 5.5 \\
\hline Prepelvic length & 30.9 & 31.4 & 21.9-35.4 & 4.1 \\
\hline Height of dorsal fin & 27.6 & 26.5 & $20.7-30.5$ & 2.6 \\
\hline Height of anal fin & 14.6 & 15.6 & $12.7-19.5$ & 2.1 \\
\hline Pectoral-fin length & 19.6 & 20.4 & $17.1-24.8$ & 2.3 \\
\hline Pelvic-fin length & 18.7 & 18.1 & $11.5-20.7$ & 2.7 \\
\hline \multicolumn{5}{|c|}{ Percentages of head length } \\
\hline Orbit diameter & 31.3 & 32.2 & $28-36$ & 2.5 \\
\hline Snout length & 23.6 & 25.3 & $20-51$ & 5.5 \\
\hline Maxillary length & 53.2 & 45.2 & $23-53$ & 5.5 \\
\hline Bony interorbital length & 24.1 & 27.0 & $21-31$ & 2.4 \\
\hline Meristics & $\mathrm{H}$ & Mean & Range & Mode \\
\hline Anal-fin rays & 45 iv & $44.0 \mathrm{iv}$ & $42-45$ iv & $45 \mathrm{iv}$ \\
\hline Pectoral-fin rays & 13 & 13.0 & $13-14$ & 13 \\
\hline Pelvic-fin rays & 7 & 7.0 & 7 & 7 \\
\hline Dorsal-fin rays & 9 ii & 9 ii & 9 ii & 9 ii \\
\hline Lateral line scales & 83 & 80.3 & $72-85$ & 81 \\
\hline Scales above lateral line & 20 & 19.8 & $18-22$ & 20 \\
\hline Scales below lateral line & 21 & 20.0 & $15-22$ & 20 \\
\hline Scales around caudal peduncle & 24 & 24.7 & $22-27$ & 24 \\
\hline
\end{tabular}




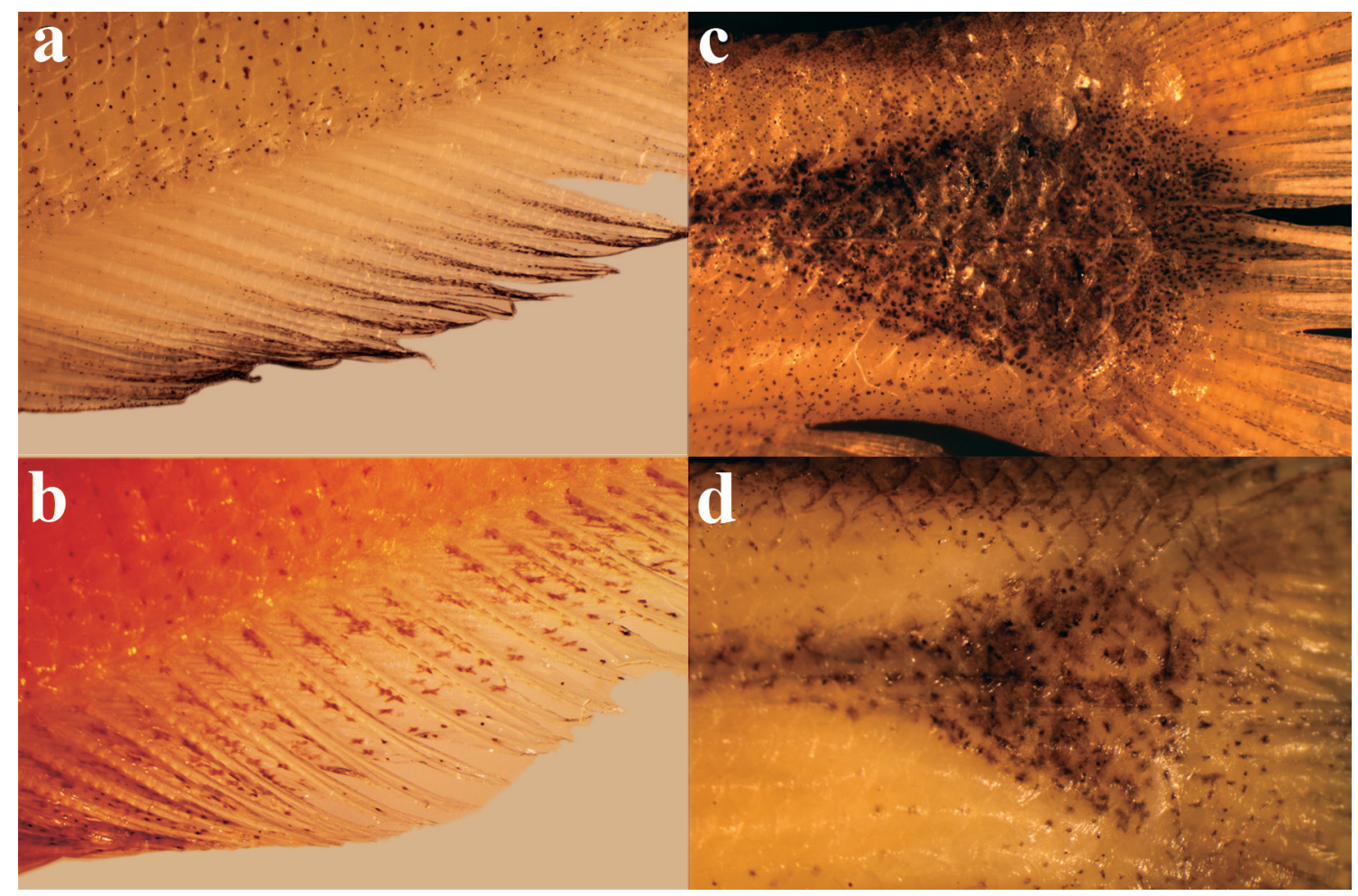

Fig. 3. (a) Anterior portion of the anal fin of Roeboides bussingi (LSUMZ 14797, $79.0 \mathrm{~mm}$ SL; paratype) showing concentration of melanophores forming a dark band at the edge of the fin. (b) Same region of anal fin of R. bouchellei (LSUMZ 14798, 72.2 $\mathrm{mm} \mathrm{SL}$ ) showing scattered melanophores, without a distinctive dark band. (c) Caudal region of $R$. bussingi showing the teardrop-shaped spot that extends onto the caudal fin. (d) Caudal region of $R$. bouchellei showing a lighter and triangleshaped spot, largely restricted to the caudal peduncle. Also note the densely distributed melanophores on the body of $R$. bussingi and the lighter body coloration and fewer melanophores in $R$. bouchellei.

shaped spot on caudal peduncle that extends to the caudal fin (rounded end on caudal fin). Dark, crescent-shaped humeral spot present (Fig. 2a), inconspicuous or absent in some specimens.

Color in alcohol. Ground color yellowish-tan. Dorsal head and flank with melanophores loosely dispersed but more concentrated than below lateral line. Dark gray mid-lateral band extending from anterior margin of opercle to black teardropshaped spot on caudal peduncle and base of middle rays of the caudal fin. Humeral spot dark brown, crescent-shaped when present. Dorsal and caudal fins whitish to transparent and with dusky distal margins, anal fin with concentrated melanophores at distal margin. Paired fins opaque (Fig. 2b, 3a).

Distribution. Roeboides bussingi is known from the Pacific slope of Costa Rica and Panama, including tributaries of the río Coto drainage in Costa Rica to the río San Pablo west of the city of David in western Panama (Fig. 1).

Etymology. The species is named after William Bussing, an exceptional ichthyologist who has devoted his professional career to the understanding of the Costa Rican and Central American ichthyofauna. He was the first to suggest that the species described herein was new to science (Bussing, 1998).

Remarks. A reduced or absent humeral spot clearly distinguishes $R$. bussingi from all other Lower Middle American species of Roeboides with the exception of $R$. bouchellei, which is nevertheless distinct from $R$. bussingi in terms of color pattern. Examination of more than 300 specimens of $R$. bouchellei revealed that the differences in coloration described in the diagnosis of $R$. bussingi are consistent, strongly indicating that the species are distinct. In addition, Bermingham et al. (1997) concluded that specimens of Roeboides from the río Coto and Western Panama are genetically distinct from other $R$. bouchellei. That might be interpreted as additional circumstantial evidence for the distinction of $R$. bussing $i$ among congeners, given that $R$. bussing $i$ is the only species of the genus known to occur in the río Coto. 


\section{Key to species of Roeboides from Middle America, adapted} from Lucena (2000).

1a. Presence of a small dark wedge-shaped spot at the lateral midline of body, located between the verticals through the anterior and posterior bases of the dorsal fin; humeral spot absent R. guatemalensis

1b. Small dark wedge-shaped spot at the lateral midline of body absent; humeral spot absent or present (usually present) .2

2a. Humeral spot absent (or very small, covering less than 4 scales) .... 3

2b. Humeral spot well developed and covering 4 or more longitudinal scales and 6 or more vertical scales in adults

3a. Body coloration light (most obvious in preserved specimens); distal tip of anal fin without dark band of melanophores; triangular caudal spot typically restricted to the caudal peduncle; 15 to 19 scales above lateral line; 14 to 20 scales below lateral line R. bouchellei

3 b. Body coloration dark, with densely distributed melanophores (most obvious in preserved specimens); distal tip of anal fin with dark band of melanophores; teardrop-shaped caudal spot extending beyond the caudal-fin peduncle, reaching the caudal fin; 18 to 22 scales above lateral line; 15 to 22 scales below lateral line R. bussingi

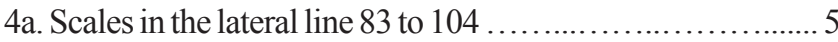

4b. Less than 82 scales in lateral line ............................ 6

5a. Maximum body depth 31.8 to $36.1 \%$ of SL; predorsal length 49.1 to $51.9 \%$ of SL ........................................ R. loftini

5 b. Maximum body depth 36.9 to $38.8 \%$ of SL; predorsal length 51.4 to $55.9 \%$ of SL ...................................... R. ilseae 6a. Scales in lateral line 60 to $73 ; 13$ to 18 scales below lateral line; anterior border of the gap between the two branches of the parasphenoid, in ventral view, close to the line between the basioccipital and preopercle ............. R. dayi

6b. Scales in lateral line 69 to $81 ; 17$ to 22 scales below lateral line; anterior border of the gap between the two branches of the parasphenoid not in the position as described above

7a. Posterior margin of humeral spot usually not reaching the vertical through the origin of the anal fin, and extending through 6 or more scales beyond the dorsal-fin origin R. occidentalis

7b. Posterior margin of humeral spot elongated in adults, extending posteriorly beyond the vertical through the origin of the anal fin, and extending through less than 4 scales beyond the dorsal-fin origin R. carti

Comparative material. Roeboides bouchellei. Costa Rica: LSUMZ 14681, 47, 23.7-34.7 mm SL, Guanacaste Province, río Congo, small shallow stream under bridge Pan-American Hwy, río Barranca drainage, $10^{\circ} 14$ '29.8'N 8459'29.8'W; LSUMZ 14696, 3, 54.8-80.3 mm SL, Guanacaste Province, Road from Umpala to
Caño Negro, small stream near farm, río San Juan drainage, 1051'07.9'N 8442'55.29.5'W; LSUMZ 14705, 1, 80.5 mm SL, Alajueal Province, drainage ditch off road to Caño Negro, surrounded by farm, río San Juan drainage, $10^{\circ} 58^{\prime} 16.8^{\prime \prime} \mathrm{N}$ 84²''58.8'W; LSUMZ 14720, 2, 33.5-37.4 mm SL, Alajuela Province, marsh in town of Medio Queso, río Sarapiqui drainage, $11^{\circ} 01$ '51.6”'N 8441'21.1'W. EI Salvador: LSUMZ 14798, 26, 62.0-71.7 mm SL, Department of Santa Ana, Lago Guija, río Lempa drainage, $14^{\circ} 14 ' 52.5^{\prime} \mathrm{N} 89^{\circ} 29^{\prime} 03$ ”'W, W.A. Matamoros, C. D. McMahan, 6 June 2011. Honduras: TU 187481, 94, 35.5-78.4 mm SL, Department of Valle, Nacaome River drainage. Nicaragua: TU 24219, 146, 25.4-94.4 mm SL, Departmento of Rivas, Sapoa River, Lake Nicaragua, Suttkus, DeAbate, Vieto and Jimenez. Guatemala: UF 115557, 15, 44.2-68.1 mm SL, Department of Escuintla, Azuchio River, Marialinda River Drainage, $23.5 \mathrm{~km}$ south of Escuintla on CA-2-Oriente.

\section{Acknowledgments}

We are grateful to Helena Molina-Ureña from the University of Costa Rica for logistical support in Costa Rica. We are also very thankful to Gisela Reina, Rigoberto Gonzales and Eyda Gomez from the Smithsonian Tropical Research Institute (STRI) for support in Panama. ANAM, in Panama, provided collection permits to CDM. We also thank two anonymous referees for their valuable comments to the manuscript and their constructive suggestions. This research was supported by NSF grant DEB0916695 to PC.

\section{Literature Cited}

Bermingham, E., S. McCafferty \& A. Martin. 1997. Fish biogeography and molecular clocks: perspectives from the Panamanian Isthmus. Pp. 113-138. In: Kocher, T. D. \& C. Stepien (Eds). Molecular Systematics of Fishes. Academic Press, NY.

Bussing, W. A. 1985. Roeboides ilseae, n. sp., a new scale-eating characid fish from Costa Rica. Revista de Biologia Tropical, 33 : 45-50.

Bussing, W. A. 1998. Peces de las aguas continentales de Costa Rica/Freshwater fishes of Costa Rica. Universidad de Costa Rica, San Jose, Costa Rica.

Fink, W. L. \& S. H. Weitzman. 1974. The so called cheirodontin fishes of Central America with descriptions of two new species (Pisces: Characidae). Smithsonian Contributions to Zoology, 172: $1-46$.

Eschmeyer, W. N. 2012. Catalog of Fishes. California Academy of Sciences. (http://research.calacademy.org/research/ ichthyology/catalog/fishcatmain.asp). Electronic version accessed Sep 2012

Hahn, N. S., C. S. Pavanelli \& E. K. Okada. 2000. Dental development and ontogenetic diet shifts of Roeboides paranensis Pignalberi (Osteichthyes, Characinae) in pools of the upper Rio Paraná floodplain (State of Parana, Brazil). Revista Brasileira de Biologia, 60: 93-99.

Lucena, C.A. S. 1998. Relações filogenéticas e definição do gênero Roeboides Günther (Ostariophysi: Characiformes: Characidae). Comunicações do Museu de Ciências e Tecnologia da PUCRS, Série Zoologia, 11: 19-59. 
Lucena, C. A. S. 2000. Revisão taxonômica e filogenia das espécies transandinas do gênero Roeboides Günther (Teleostei: Ostariophysi: Characiformes). Comunicações do Museu de Ciências e Tecnologia da PUCRS, Série Zoologia, 13: 3-63.

Lucena, C. A. S. 2003. Revisão Taxonômica e Relacões Filogenéticas das espécies de Roeboides grupo-microlepis (Ostariophysi; Characiformes; Characidae). Iheringia, Série Zoologia, 93: 283308.

Lucena, C. A. S. 2007. Revisão taxonômica das espécies do gênero Roeboides grupo-affins (Ostariophysi, Characiformes, Characidae). Iheringia, Série Zoologia, 97: 117-136.

Lucena, C. A. S. 2011. A new species of Roeboides from Panama (Characiformes: Characidae). Revista de Biología Tropical, 4: 1663-1667.

Miller, R. R., W. L. Minckley \& S. M. Norris. 2005. Freshwater Fishes of Mexico, University of Chicago Press, Chicago.

Submitted January 8, 2013 Accepted March 19, 2013 by Fabio Di Dario

Published June 28, 2013 